\title{
10. VARIATION OF TRACE FOSSILS AND ICHNOFACIES IN NEOGENE AND QUATERNARY PELAGIC SEDIMENTS FROM THE EASTERN EQUATORIAL PACIFIC OCEAN (LEG 138) ${ }^{1}$
}

\author{
Alan E.S. Kemp ${ }^{2}$
}

\begin{abstract}
Analysis of the incidence and relative abundance of trace fossils in sediments from the eastern equatorial Pacific Ocean reveals distinct patterns of occurrence. A major control on variation in ichnofacies appears to be the organic carbon content of the sediments. Ichnofacies dominated by Zoophycos are characteristic of sites having diatomaceous sediments that are relatively rich in organic matter $(0.5 \%-1.5 \%)$. Isolated Zoophycos burrows occur in darker, diatom-rich interbeds within nannofossil ooze sections. In thick, variably diatomaceous nannofossil oozes having lower $\mathrm{C}_{\text {org }}$ contents $(0.1 \%-0.3 \%)$, but with pyrite or monosulfide, Chondrites is more evident and Zoophycos rarer. Sections characterized by the lowest sedimentation rates and $\mathrm{C}_{\text {org }}$ concentrations between $0 \%$ and $0.1 \%$, commonly include Skolithos, which is rare or absent in other ichnofacies. A series of large, subvertical, and open burrows, not previously described in deep-sea cores, is suggested to be the product of echiuran worms.
\end{abstract}

\section{INTRODUCTION}

Trace fossils constitute a major portion of the observable structures within deep-sea cores. Several descriptive accounts of the variety of trace fossils present in DSDP cores (e.g., Ekdale, 1977, 1978, 1980; Fütterer, 1984) have been written, yet relatively few ODP/DSDP authors have attempted to document systematically their occurrence during routine core description (e.g., Wetzel, 1987; Wetzel and Wijayananda, 1990; Droser and Bottjer, 1991). The $5500 \mathrm{~m}$ of sediment recovered from the eastern equatorial Pacific during Leg 138 provided an ideal opportunity to document the spatial and temporal variations in trace-fossil diversity and abundance in a wide range of deep-sea pelagic sediment facies from ooze to clay.

Previous studies of trace fossils from the equatorial Pacific Ocean have largely been made from observations of the sediment surface or box cores (Ekdale and Berger, 1978; Berger et al., 1979); thus, there is little directly comparable published work on deep sediment cores from this region. Box cores that include the sediment surface, show a characteristic vertical zonation or "tiering" of trace fossils beneath the surface mixed layer, defined by cross-cutting relationships (e.g., Wetzel, 1991). The trace fossils preserved in deep-sea cores represent the last imposed burrows beneath the surface mixed layer of 5 to 7 cm (Berger et al., 1979; Ekdale et al., 1984). A considerable variety exists in the range of these last imposed trace fossils in deep-sea sediments; Bromley (1990) and Wetzel (1991) reviewed the inferences that one might make from this variation. The following account is a summary of the variation in types of trace fossils encountered during Leg 138 drilling and a synthesis of variation in ichnofacies from equatorial Pacific sediments (Fig. 1).

\section{AREA OF INVESTIGATION AND GENERAL SEDIMENTOLOGY}

The sediments of the eastern equatorial Pacific record the history of divergence-driven upwelling and the evolution and interaction of complex equatorial circulation systems (Fig. 2). The 11 sites occupied during Leg 138 are located in the Guatemala Basin (Sites 844, 845); south (846) and west (847) of the Galapagos, and in a north-south

'Pisias, N.G., Mayer, L.A., Janecek, T.R., Palmer-Julson, A., and van Andel, T.H. (Eds.), 1995. Proc. ODP, Sci. Results, 138: College Station, TX (Ocean Drilling Program).

Department of Oceanography, University of Southampton, Southampton, SO95NH United Kingdom. equatorial transect (Sites 848 through 854 ) centered on $110^{\circ} \mathrm{W}$ (Fig. 1). Water depths of sites lie within the range of $3296 \mathrm{~m}$ (846) to $3855 \mathrm{~m}$ (848). The Guatemala Basin sites contain early to middle Miocene nannofossil ooze, followed by late Miocene through Pleistocene siliceous clay (Figs. 3, 4, and 5). Site 846, located beneath the Peru Current, comprises early Miocene through early Pliocene nannofossil ooze, followed by Pliocene through Pleistocene diatom nannofossil ooze. The near-equator sites $(847,849,850,851)$ were dominated throughout middle Miocene through Pleistocene time by diatom nannofossil ooze (Figs. 6, 7, and 8). Intervals of diatom ooze, sometimes laminated, occur intermittently in these near-equator sites (Kemp and Baldauf, 1993). Sites outboard of the innermost equatorial zone contain late Miocene through early Pliocene nannofossil ooze, followed by late Pliocene through Pleistocene foraminiferal nannofossil ooze. The offequator sites $(853,854)$ contain nannofossil ooze and clays. Superimposed on these major spatial and temporal patterns of sediment distribution are pervasive, high-frequency, meter- to decimeter-scale variations in sediment color and composition (see below). The sedimentary history of the region is summarized by Kemp (this volume).

\section{VARIATION IN BIOTURBATION INTENSITY-"ICHNOFABRIC INDEXES"}

During Leg 138, the intensity of visible bioturbation was recorded on "barrel sheets" using the usual ODP scheme of four categories: none, slight, moderate, and heavy. However, it was apparent through most of the Leg 138 cores that the intensity of visible bioturbation was consistently greater when a primary bedding color variation was observed within the cores (PI. 2, Fig. 2). Apparent (visible) bioturbation intensity, therefore, probably does not reflect accurately true variation in overall intensity of bioturbation, but rather, the presence of sufficient color contrast.

Droser and Bottjer (1986) proposed a scheme for quantifying "ichnofabrics" using the extent of disruption of original bedding features by bioturbation. This scheme was adapted (Droser and Bottjer, 1991) for use when describing deep-sea sediments by adding categories to describe "the discrete trace fossils emplaced last on a background of completely homogenized sediment." However, much of the $5.5 \mathrm{~km}$ of sediment encountered during Leg 138 drilling contained a regular, decimeter- to meter-scale alternation between thinner darker beds or bands and thicker paler intervals. This typical bedding alternation is commonly from thicker, more featureless, white nannofossil ooze to thinner beds of darker, radiolarian-bearing nannofossil ooze (Fig. 2; Pl. 2, Fig. 2). Thus, most of the sediments encountered con- 


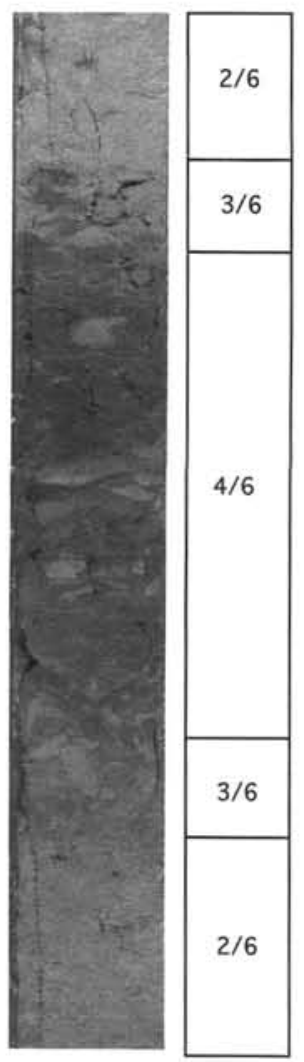

Figure 1. An illustration of the normal cyclic variation in the ichnofabric indexes of Droser and Bottjer (1991) within the sediments recovered from the eastern equatorial Pacific during Leg 138 drilling. There is a regular variation from paler sediment, in which little or no burrowing is visible, to thinner beds of darker (more siliceous microfossil-rich) sediment, in which redistribution of pale/dark sediment has made burrowing easily discernible (Section 138$851 \mathrm{E}-26 \mathrm{X}-1,55-110 \mathrm{~cm}$ ).

tained a high-frequency variability in ichnofabric indexes (Fig. 2). This alternation has been interpreted to represent a sedimentary response to orbital (Milankovitch-band) forcing (see Shackleton, this volume).

\section{IDENTIFICATION OF TRACE FOSSILS}

The greatest problem encountered when identifying trace fossils (and other visual core descriptions) was the variable quality of the cut surface of the core. Cores were cut using wire until this proved ineffective, generally at a depth of between 200 and $300 \mathrm{~m}$. All wire-cut cores were scraped with microscope slides prior to description and color analysis (see Mix et al., this volume). This scraping generally produced good-quality core surfaces for description for about the top 100 to $150 \mathrm{~m}$ (depending on lithology). However, between these depths and the start of saw-cut surfaces, structures were indistinct and discrete trace fossils were difficult to discern. Chondrites, especially, was often noted as occurring in abundance within the first saw-cut core, but not having been recognized in preceding wire-cut cores of otherwise similar lithology. An extreme case of the contrast between wire- and saw-cut surfaces is shown in Plate 1, Figures 1 and 2. In this case, wire-cutting considerably deformed and obscured the laminations (see also chapters by Kemp and others, this volume).

\section{RESULTS}

The occurrence and abundance of the most commonly encountered trace fossils in selected sites are shown in Figures 4 through 8 and illustrated in Plates 1 through 5. During routine shipboard core descrip-

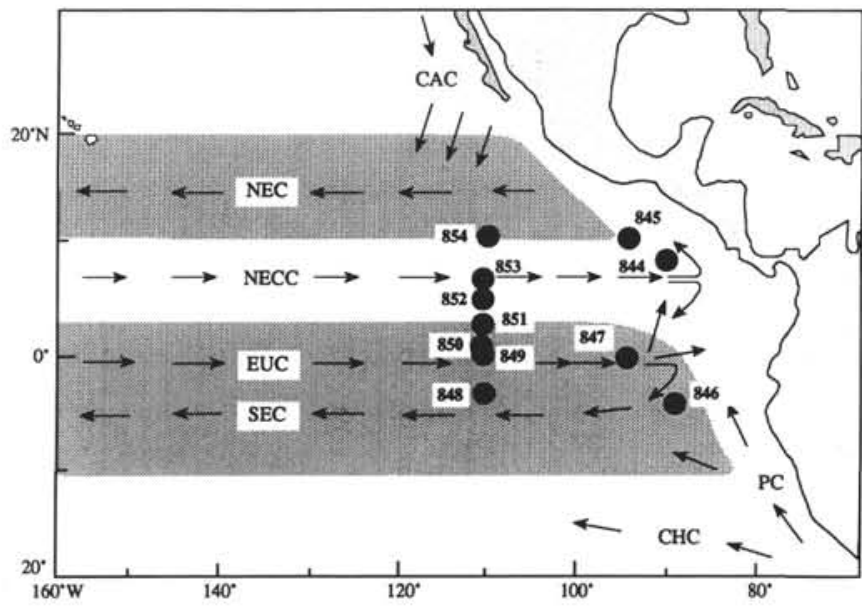

Figure 2. Location map for Leg 138 sites showing position with respect to major current systems of the eastern equatorial Pacific Ocean. Solid arrows indicate surface currents; dashed arrows indicate subsurface currents. $\mathrm{CAC}=$ California Current; NEC $=$ North Equatorial Current; NECC $=$ North Equatorial Countercurrent; $\mathrm{EUC}=$ Equatorial Undercurrent; $\mathrm{SEC}=$ South Equatorial Current; $\mathrm{PC}=$ Peru Current CHC $=$ Chile Current. Shaded areas indicate the general latitudinal extent of the SEC and NEC.

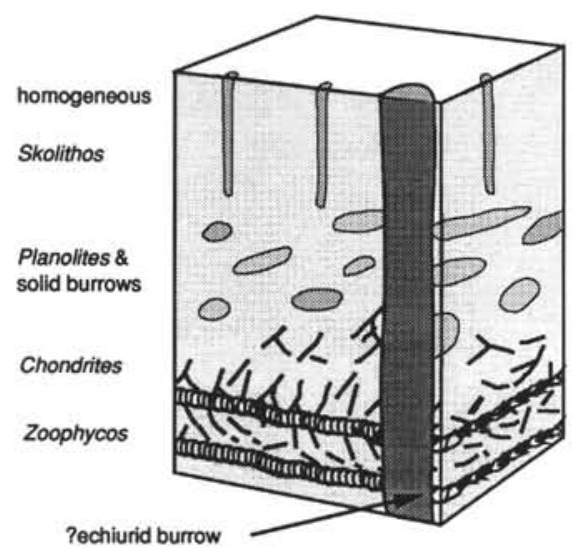

Figure 3. Schematic vertical zonation of the common burrows encountered in sediment cores from the eastern equatorial Pacific Ocean.

tion, the following trace fossils were noted: Skolithos, Planolites, solid burrows, rind burrows, Chondrites, and Zoophycos. Teichichnus was recognized rarely on saw-cut surfaces. In addition, the presence of open burrows and other burrows, not obviously falling into the above categories, was noted. Shipboard and shore-based quality control checks were performed for these determinations using core photos and by re-examination of selected intervals at the ODP Gulf Coast Repository. Because of overlapping usage, the categories Planolites and solid burrows have been combined. No burrows having the characteristic fill structure of Thalassinoides occur, nor was Phycosiphon recognized. The term "rind burrow" was used to describe burrows having diagenetic, reaction-front "haloes," as well as burrows having true (several millimeter- to centimeter-scale) rinds (see below). The range of common trace fossils recognized is shown schematically in Figure 3 , in what might have been an original tiered structure.

\section{Laminated Diatom Ooze}

The only lithology in which the true extent of bioturbation could be confidently assessed was laminated diatom ooze in sections cut by 


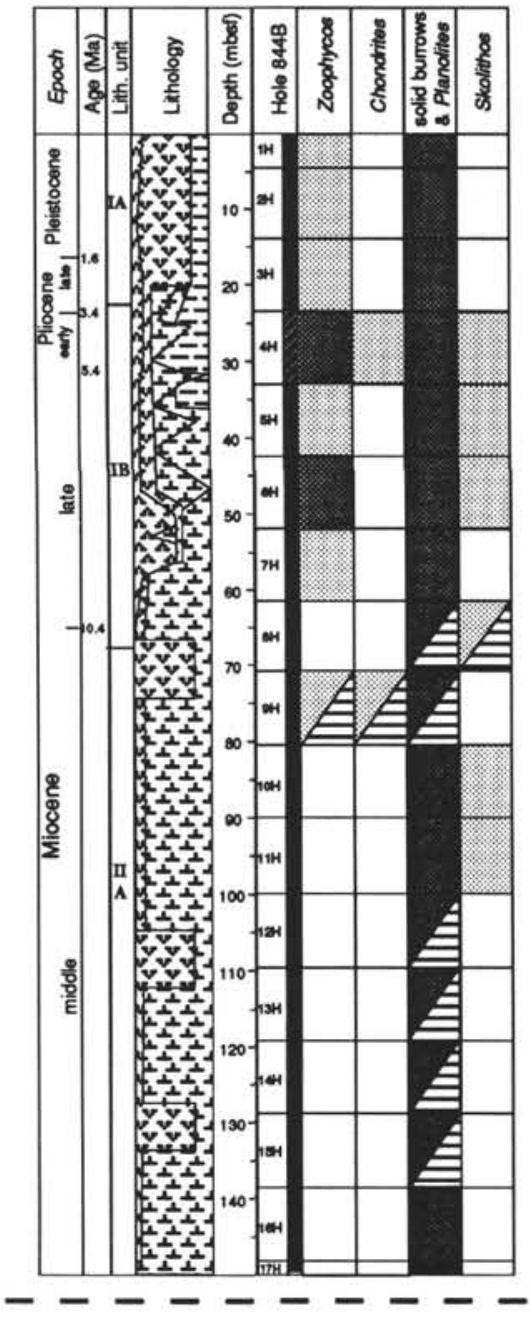

Key for Figs. 4 -8

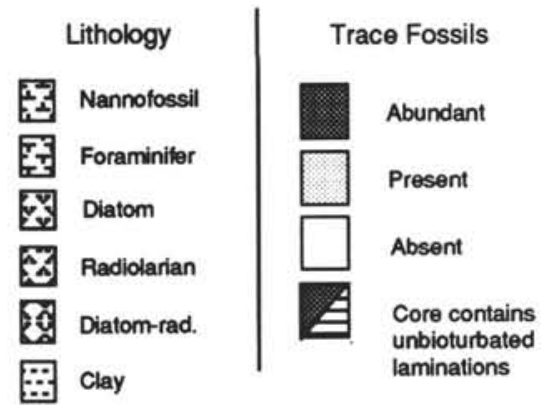

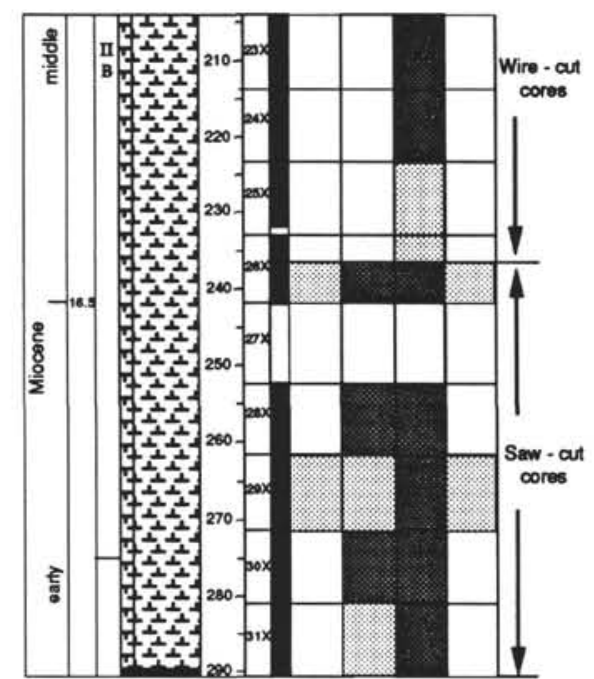

Figure 4. A summary of the depth distribution of trace fossils encountered at Site 844, with key that applies to Figures 4 through 8.

the saw. Several sections of this lithology can be seen in Sites 850 and 851 , in which, clearly, no macroscopic bioturbation of any kind can be seen $(\mathrm{Pl} .1)$. The preservation of lamination within these intervals is thought to relate to the physical suppression of benthic burrowers by mats of the diatom Thalassiothrix longissima (Kemp and Baldauf, 1993; Kemp et al., this volume; King et al., this volume).

\section{Skolithos}

Skolithos is never abundant in Leg 138 cores. Berger et al. (1979) emphasized the smaller probability of encountering vertical burrows within cores, and, as a relatively shallow burrow (Pl. 2, Fig. 2), Skolithos is more prone to destruction by deeper burrowers. Skolithos 


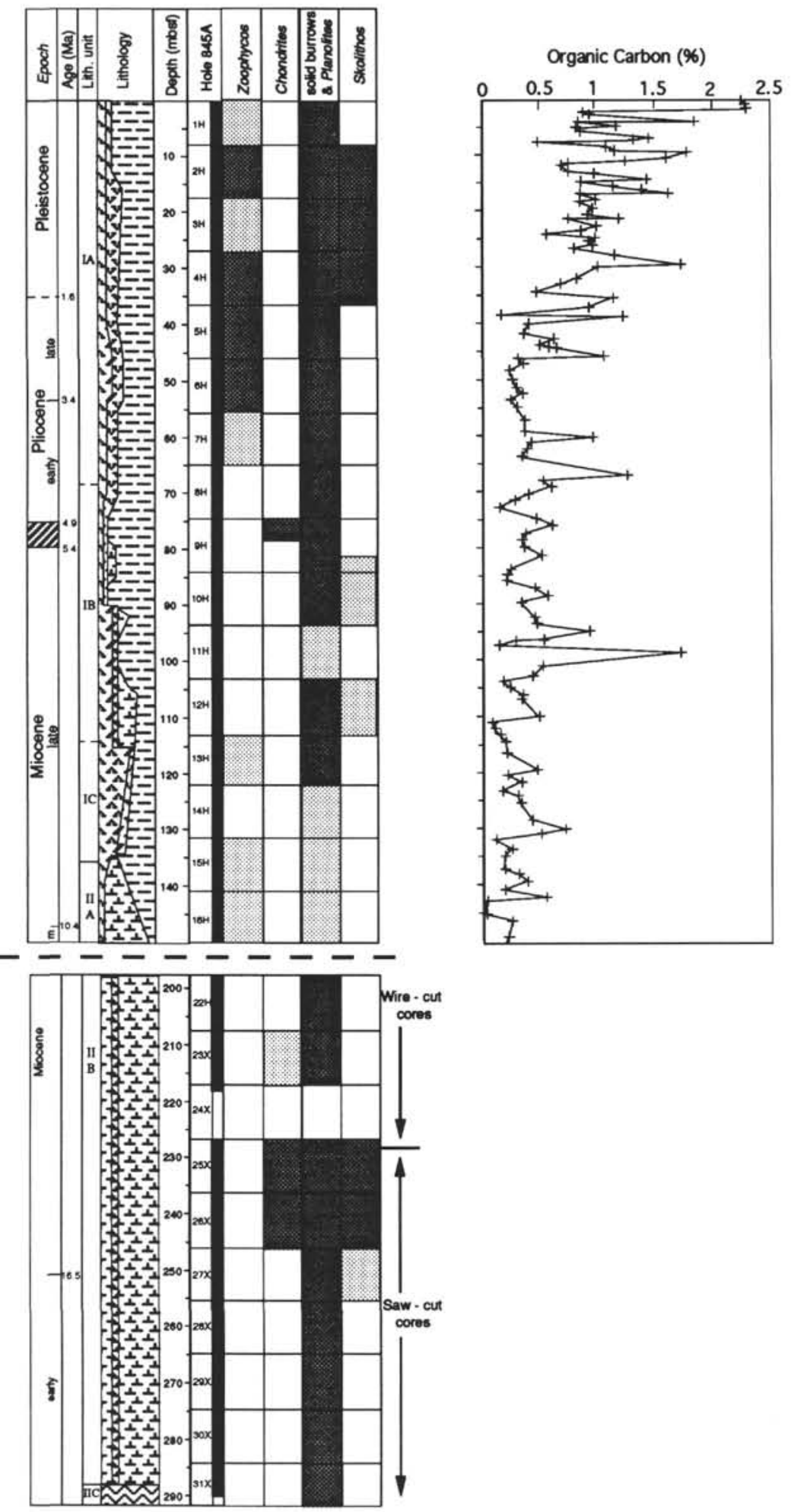

Figure 5. A summary of the depth distribution of trace fossils encountered at Site 845, together with shipboard organic carbon determinations.

is more common in the off-equator sites in the equatorial transect (Sites 848 and 852 through 854 ), where probably less incentive existed for deeper burrowers. Only at Site 846 are numerous vertical burrows encountered. Because these are significantly larger than the normal size range quoted for Skolithos, they have been discussed separately (below).

\section{Planolites and Solid Burrows}

Planolites and "solid" or "massive" burrows are the most consistently abundant burrows recognized in Leg 138 sediments (Pls. 2 through 4). During shipboard core description, an overlapping usage existed between these distinct burrow features and what some workers 

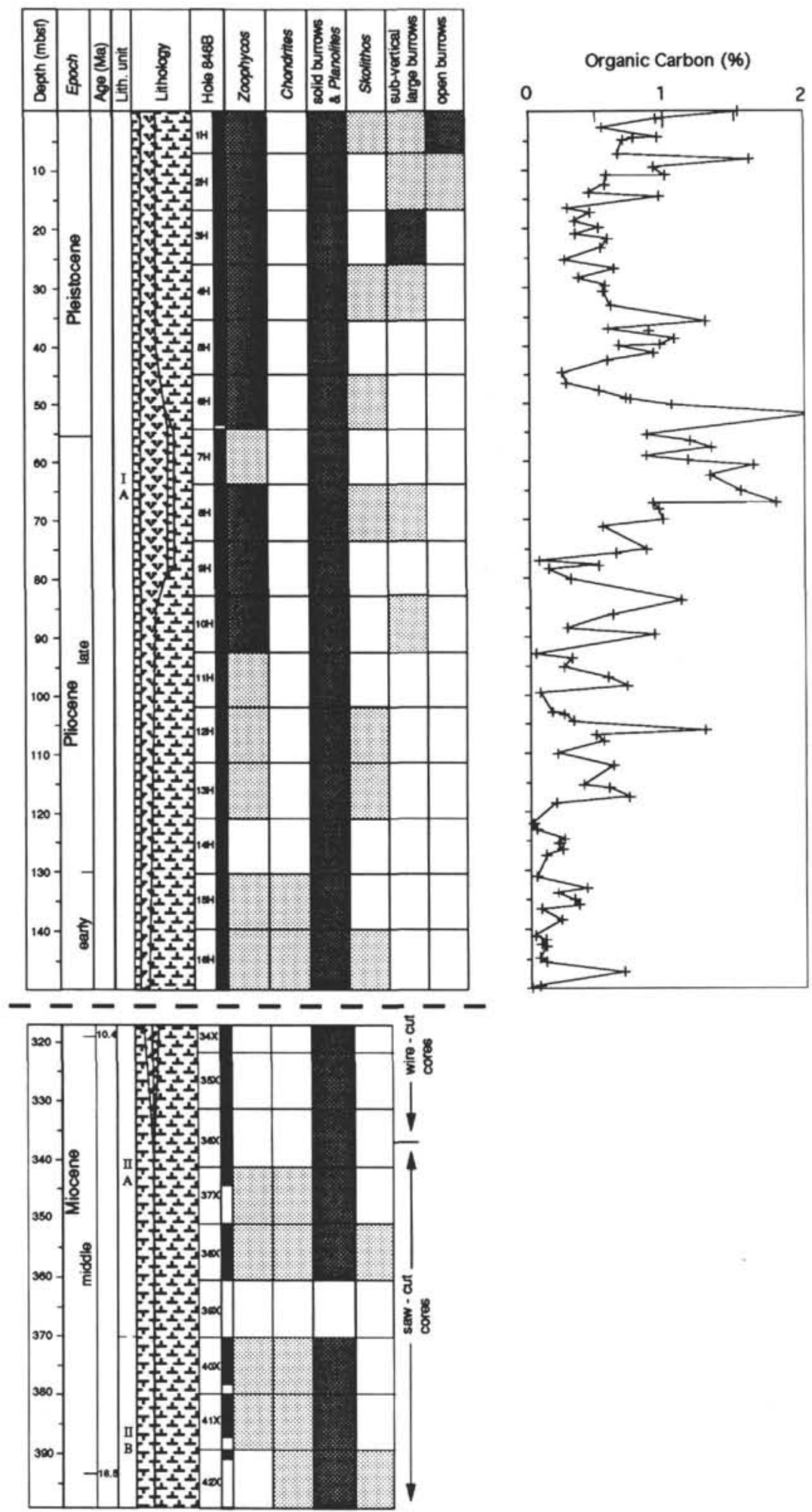

Figure 6. A summary of the depth distribution of trace fossils encountered at Site 846, together with shipboard organic carbon determinations.

called "biodeformational structures" or indistinct burrows (Wetzel and Werner, 1981). However, the indistinct nature of these structures often resulted from the poorer quality of wire-cut core surfaces. Within this range of structures, great variation can be seen in the nature of the burrow fill. In many cases, the different-colored fill appears compositionally identical to the surrounding sediment. However, in several intervals, burrow fills are compositionally distinct, generally being more diatom-rich than the enclosing carbonate sediment. In upper Miocene sediments at Site 852, abundant burrow fills contain near monospecific floras of Thalassiothrix longissima that probably represent an off-center expression of the ca. 10 Ma diatom mat-forming event (Kemp and Baldauf, op. cit.). Diatom-rich burrow fills also are 


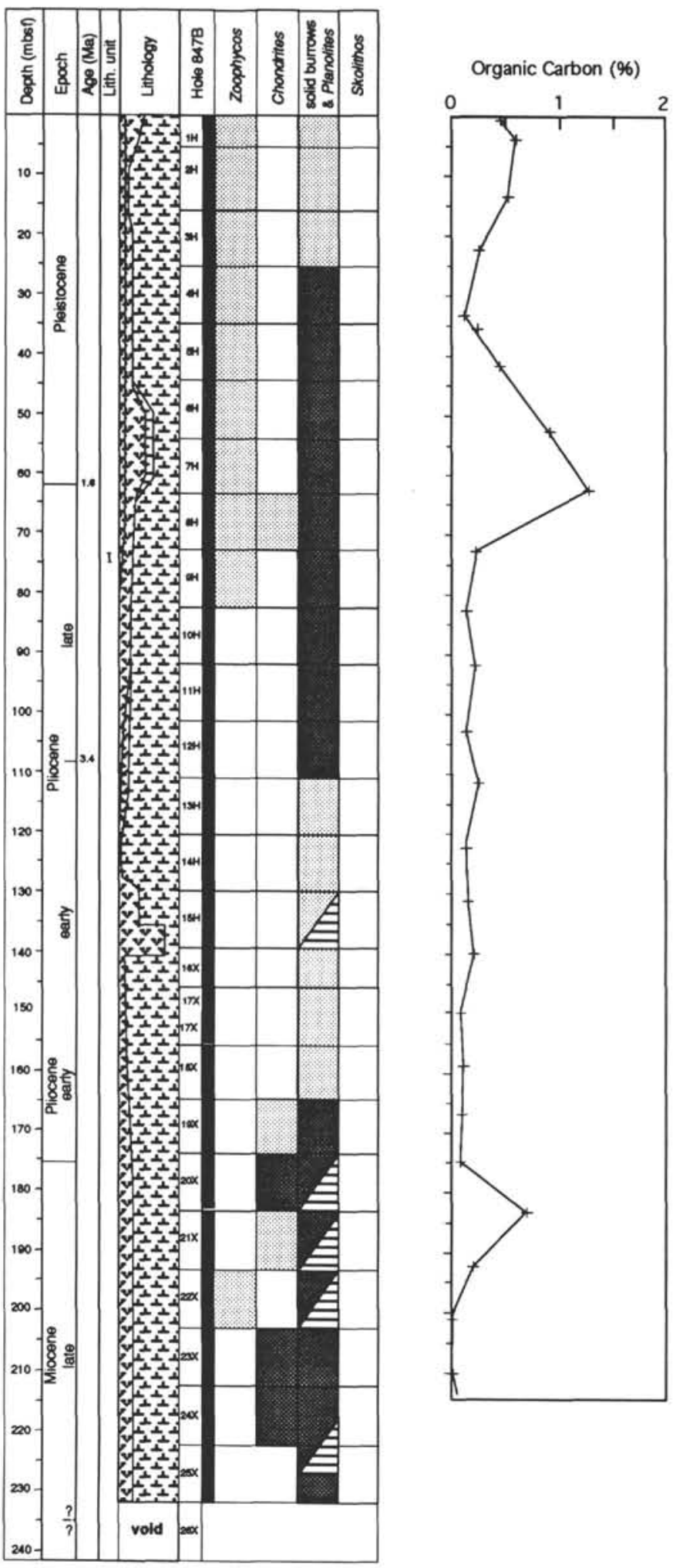

Figure 7. A summary of the depth distribution of trace fossils encountered at Site 847 , together with shipboard organic carbon determinations.

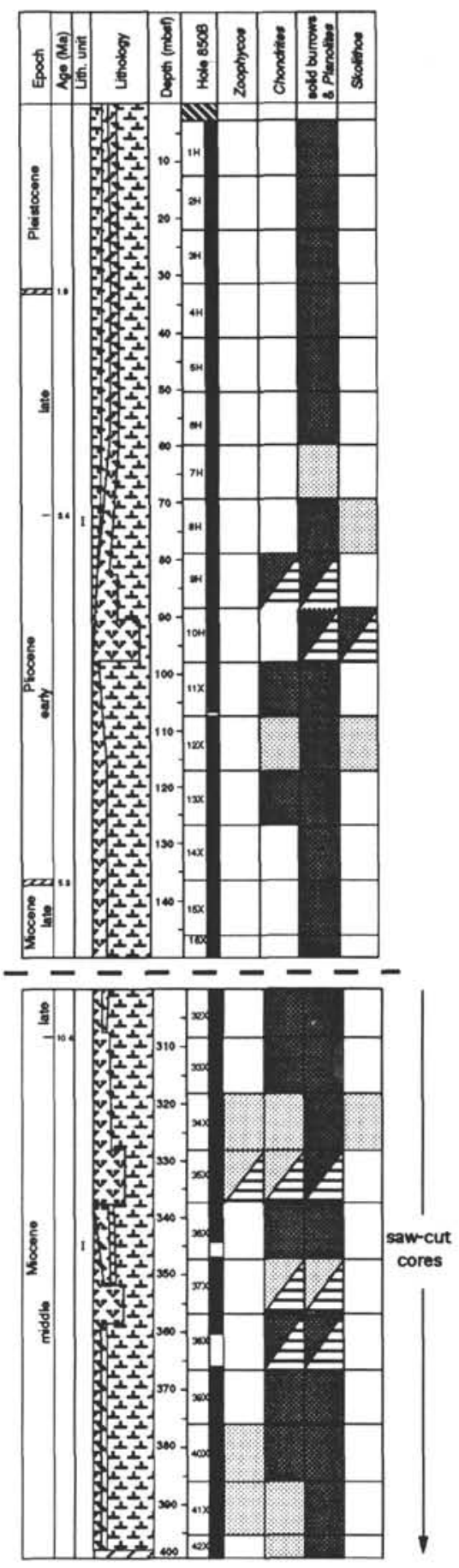

Figure 8. A summary of the depth distribution of trace fossils encountered at Site 850 . Organic carbon values are consistently about $0.2 \%$ to $0.3 \%$. 
common within the nannofossil ooze interbedded with laminated diatom ooze and commonly dominate the appearance of the sediment.

\section{Rind and Halo Burrows}

Classical rind burrows possess a distinctive, paler-colored rind of sediment of the order of several millimeters thick (Pl. 2, Fig. 3). These are confined to sediments characterized by lower sedimentation rates and oxic to suboxic diagenetic environments in sites that are off the axis of the equatorial high-productivity belt (e.g., 848 and 852), or to intervals of slow sedimentation rate within the higher productivity sites. Halo burrows, in contrast, generally have a millimeter-tosubmillimeter dark bluish-black loop or line (depending on burrow orientation), which may be from a few millimeters to several centimeters from the actual burrow margin (Pl. 2, Fig. 5; Pl. 3, Fig 4; Pl. 4, Fig 4; Pl. 5). The haloes are a bluish-black color and are sometimes gradational to, or contiguous with, a general bluish-black mottling within the sediment (Pl. 4, Fig 4; Pl. 5). These halo burrows are most abundant in sites having high sedimentation rates that show evidence for anoxic sulfidic diagenesis (sensu Berner, 1981), including the presence of pyrite framboids. Note that in the descriptions of trace fossils given in the barrel sheets (Mayer, Pisias, Janecek, et al., 1992) the term "rind burrow" was used for both the above structures.

\section{Chondrites}

Within the eastern sites $(844,845)$, Chondrites is very rare within the upper siliceous/clay-rich intervals, but is present to common within the middle and lower carbonate-rich sections, where it is frequently observed cutting Planolites burrows and is commonly restricted to burrow fills. This is a pattern that is repeated at Sites 846 and 847 (although the upper intervals in these sites are more carbonate-rich). Completely pyritized Chondrites burrows occur within the late Miocene age nannofossil oozes at Site 847. A problem with the systematic description of Chondrites is that it is much less readily recognized on the poorly cut surfaces of the lower wire-cut sections. In the near equatorial sites ( 848 through 851 ), Chondrites is seldom observed within the upper sections, except occasionally within burrow fills. At Site 849, no Chondrites was observed within the top 150 $\mathrm{m}$, and at Site 850 , observed only once in the upper $76 \mathrm{~m}$, although it is common within the more diatom-rich sediments below this depth. At intermediate depths, Chondrites is difficult to recognize, but within the saw-cut lower intervals, Chondrites is common to abundant (e.g., Site 850 , Fig. 8). At Site 851 , Chondrites was observed only once within the foraminifer nannofossil ooze of the upper $75 \mathrm{~m}$ but, as at Site 850 , was observed commonly in the diatom nannofossil ooze below this, as were bluish-black, monosulfide- or pyrite-bearing, burrow fills. Within the northern sites (852-854), Chondrites is rare, being generally restricted to burrow fills. Chondrites burrows may cut Zoophycos burrows, except in the upper sections of Sites 845 through 847, where Chondrites is rare or absent.

\section{Zoophycos}

Considerable variation was observed in both the mode of occurrence and the size of Zoophycos, with the most abundant developments being at Sites 844 through 847 . At Site 844, Zoophycos was consistently observed within the mixed siliceous clay and carbonate facies in Subunits IA and IB (of late Miocene through Pleistocene age) and is locally abundant within the interbedded siliceous and carbonate oozes between 25 and 60 mbsf (Fig. 3). Series or stacks of more than three spreiten are rare. Two forms were observed: (1) a thicker form with spreiten between 3 and $8 \mathrm{~mm}$ thick and (2) a less common, thin form with spreiten consistently around $2 \mathrm{~mm}$ thick (PI. 4, Fig. 3). The thin form appears to be more common in sediments of carbonate or transitional composition than in the siliceous sediments. In the carbonate-rich sediments of Site 844 , lithologic Unit II, below 68 mbsf, only rare individual Zoophycos spreiten occur. Isolated, individual Zoophycos can be more commonly observed in the saw-cut cores of nannofossil ooze below 237 mbsf.

Among all the Leg 138 cores, Zoophycos is most abundant within the upper siliceous clay facies of Site 845 (Fig 4; Pl. 3, Figs. 1 through 3 ), where series or stacks of spreiten are common. Individual stacks are up to $27 \mathrm{~cm}$ in overall vertical extension and contain up to 10 spreiten. The thickness of individual spreiten varies from 6 to $12 \mathrm{~mm}$. Some spreiten display unusually high $\left(50^{\circ}\right)$ angles of climb (Pl. 3, Fig. 3). A remarkable correspondence was observed between almost identical stacks of Zoophycos burrows in Sections 138-845A-5H-3, $120-145 \mathrm{~cm}$ ( $40.5 \mathrm{mbsf}$ ), and 138-845B-4H-6, 77-102 cm (40 mbsf) (PI. 3, Figs. 1 and 2). With a (theoretical) offset of about $20 \mathrm{~m}$ between Hole $845 \mathrm{~A}$ and Hole $845 \mathrm{~B}$, this correlation implies considerable lateral persistence of burrowing (see discussion below).

Zoophycos is also consistently abundant in the diatom nannofossil ooze of the upper $90 \mathrm{~m}$ of Site 846 . The thickness of individual spreiten here varies from 6 to $10 \mathrm{~mm}$ and is most commonly about 8 $\mathrm{mm}$. Stacks of spreiten do occur (PI. 5, Fig. 2), but are not as abundant as at Site 845 . Zoophycos burrows are cut by both open burrows (PI. 5, Fig. 2) and by large subvertical burrows (Pl. 5, Fig. 4; see below). A distinct decrease is seen in the abundance of Zoophycos from about $90 \mathrm{mbsf}$. In the nannofossil oozes and chalks of Unit II, thinner (about $3 \mathrm{~mm}$ ) Zoophycos are occasionally present.

At Site 847, isolated Zoophycos spreiten are common from 0 to 90 mbsf, but are very rare below this depth (Fig. 7). It is particularly common in the top $15 \mathrm{~m}$ and between 40 and $75 \mathrm{mbsf}$ in the more diatom-rich interval (late Pliocene high productivity event, see Kemp, this volume). Zoophycos was observed only within the darker diatomrich layers, where the general level of bioturbation appears less than that of the surrounding carbonate sediments (Pl. 3, Fig. 4).

Within the equatorial transect (Sites 848 through 854), Zoophycos generally occurs only as isolated spreiten and is rare in the sediments recovered from the higher sedimentation sites (849-851), except in more diatom-rich intervals, such as the ca. 10.5- to 9.5-Ma high-productivity event at Site 849 (305-315 mbsf), where it is common, and the latest Pliocene diatom-rich interbeds at Site 848 (late Pliocene high-productivity event). It is generally rarely observed in carbonaterich facies, but individual spreiten are not uncommon among intervals having darker, more diatom- and/or radiolarian-rich interbeds. Zoophycos, occurring as isolated spreiten, is more common in the alternating oxide-rich interbeds in the upper section of Site 852 and was more consistently observed in the alternating pale to dark brown clays and oxide-rich nannofossil ooze within Sites 853 and 854, which have much lower sedimentation rates $(5-15 \mathrm{~m} / \mathrm{m} . \mathrm{y}$.).

\section{Large Subvertical and Open Burrows}

A series of large subvertical burrows were recognized that were unique to Site 846 (Pl. 5). These are about 1.5 to $2 \mathrm{~cm}$ in diameter and commonly exceed $50 \mathrm{~cm}$ in vertical extent, up to a maximum of 1.1 $\mathrm{m}$. Individual burrows are surrounded by a reaction front or halo that commonly extends between 2 and $4 \mathrm{~cm}$ from the burrow margin. This early diagenetic feature substantially aids identification of the density and vertical extent of these remarkable structures. Several of these burrows were observed to terminate downward in an L-shaped curve. Subvertical burrows cut other trace fossils, such as Zoophycos (also common to abundant in the upper part of Site 846). The fill of subvertical burrows is commonly exotic with respect to the enclosing sediment and often contains more fluid-rich sediment or displays different consistency. Clearly, this evidence for substantial sediment redistribution has serious implications for paleoceanographic studies within these intervals. The subvertical burrows are common in all three holes drilled at Site 846 between 5 and 40 mbsf, being most abundant between 15 and 40 mbsf. In Hole 846B, large vertical burrows also were recognized at 70 and $80 \mathrm{mbsf}$ in sediments of late Pliocene age.

A close association can be seen between these subvertical burrows and the large, open burrows of similar $(1.5-2 \mathrm{~cm})$ diameter that are 
common within the top $12 \mathrm{~m}$ and are also unique to Site 846 . Both the subvertical and open burrows truncate other burrows, including deep tiers such as Zoophycos (PI. 5 Figs. 1, 4). These open burrows are considerably larger and deeper than previously reported occurrences (e.g., Weaver and Schultheiss, 1983). A large, 9-cm-wide, composite, oblique structure, composed of exotic material, cuts the sediment within this interval (Pl. 5, Fig. 6) and may also be associated with these large burrows.

There is no doubt that the haloes around burrows in the upper section of Site 846 help to identify these structures. It is possible that the large vertical burrows are present in other intervals, but if so, are rare and appear to intersect the core only as solid burrows.

\section{DISCUSSION}

Bromley, in his 1990 treatise, rightly emphasized the need for caution when interpreting ichnocoenoses: "Simplistic models relating ethological interpretation to environmental types may work at a general level, but they often mislead more than help." This caveat notwithstanding, several new insights into deep-sea ichnology stem from the above observations.

\section{Chondrites}

Chondrites is common within Miocene through early Pliocene age nannofossil and diatom nannofossil oozes. Abundances are often greatest in intervals containing bluish-black mottling and disseminated framboidal pyrite (observed in the cores and in smear slides) and, in some cases, the Chondrites burrows themselves may be pyritized. This association suggests an affinity of Chondrites with strongly reducing conditions and/or the lower abundance of other deeper-tier bioturbation (e.g., Zoophycos) that might obliterate Chondrites in such conditions. Significantly, the sites that have relatively high $\mathrm{C}_{\text {or }}$ values but lack Chondrites, (upper sections of Sites 844,845 , and 846) do not contain pyrite, yet contain abundant Zoophycos (see next section). It should be emphasized that it is sediment/pore-water anoxia, not bottom-water anoxia, that is implied here.

\section{Zoophycos}

A good correlation exists between the most abundant occurrences of Zoophycos and the highest recorded concentrations of organic matter. Zoophycos occurs in greatest abundance within the top $50 \mathrm{~m}$ of Site 845 , where $\mathrm{C}_{\mathrm{org}}$ concentrations are commonly about $1 \%$. Measurements of $\mathrm{C}_{\mathrm{org}}$ at Site 844 are incomplete, but relatively high values in the upper section coincide with the presence of Zoophycos. Site 846, which also has abundant Zoophycos, has concentrations of $\mathrm{C}_{\text {org }}$ of between $0.5 \%$ and $1 \%$, sometimes higher in the upper section. The sparse $\mathrm{C}_{\text {org }}$ data available for Site 847 indicate higher $\mathrm{C}_{\mathrm{org}}$ concentrations for the upper $70 \mathrm{~m}$, in which Zoophycos is intermittently, but persistently, present. (In the other sites, $\mathrm{C}_{\text {org }}$ concentrations are generally between $0.1 \%$ and $0.3 \%$.) These data support the conclusions of Wetzel and Werner (1981), who demonstrated an increased occurrence of Zoophycos with higher organic-matter concentrations in deep-sea sediments off Northwest Africa. In such cases, higher concentrations of organic matter seem to have provided an increased incentive to the Zoophycos producer to burrow deeply within the sediment, ensuring preservation of its spreiten below the surface mixed layer. The localization of isolated Zoophycos within discrete darker (diatom- and $\mathrm{C}_{\text {org }}$-rich) beds further supports the affinity of Zoophycos for a rich benthic food source. Little support is seen for control by sedimentation rate, as suggested by Wetzel (1991), because the upper Zoophycos-rich sections at Site 845 have sedimentation rates that vary from 10 to 20 $\mathrm{m} / \mathrm{m}$.y., and the equivalent sections at Site 846 have rates of between 35 and $55 \mathrm{~m} / \mathrm{m} . \mathrm{y}$.

The close correlation between stacks of Zoophycos spreiten, probably meters apart (Pl. 3, Figs. 1,2), provides intriguing evidence in the search for the enigmatic and elusive originator of Zoophycos burrows. This evidence implies either much greater lateral persistence of individual, contiguous spreiten, or (perhaps more likely) that the Zoophycos producer moved over (or through) the sediment to another location and produced an almost identical burrow pattern.

\section{Large Subvertical and Open Burrows: Possible Echiuran Worm Burrows}

The close association between the large vertical burrows and the open ones (Pl. 5) suggests that the same animal may have been responsible for their formation. The most likely candidate for originator of these burrows appears to be an echiuran worm that occupied a U-shaped burrow within the sediment and fed, by way of a proboscis (extendable to 10 times its body length), on the surface, producing a rosette pattern (Fig. 9). The burrows of the shallow-water form, Echiurus echiurus, are known to have penetrated to depths of $50 \mathrm{~cm}$ below the surface (Rachor and Bartel, 1981) and those of Maxmuelleria lankesteri, at least $55 \mathrm{~cm}$ (Swift, 1993). Little is known of the range of burrow morphology and size of deep-sea echiurans. Ohta (1984) proposed that deep-sea echiurans may have inhabited L-shaped burrows, rather than the U-shaped burrows of shallow-water forms. Berger et al. (1979) found a relatively small (about $6 \mathrm{~cm}$ ) echiuran of the family Bonellidae at about $6 \mathrm{~cm}$ below the surface at a site in the eastern equatorial Pacific Ocean at a water depth of $4617 \mathrm{~m}$. However, other bonelliid echiurans are known to have body lengths up to $30 \mathrm{~cm}$ and probosces that extend up to $3.5 \mathrm{~m}$ (De Vaugelas, 1989).

The reason for the apparently unique presence of the large burrows at Site 846 remains unclear. Concentrations of $C_{\text {org }}$ at Site 846 are relatively high, but not as high as those of Site 845 , where there is no evidence of the large burrows. Indeed, Site 846 is the shallowest site at $3296 \mathrm{~m}$, but only by a few hundred meters. It is intriguing that these possible echiuran burrows have had a prolonged history of occurrence at Site 846, commencing during late Pliocene time. Whatever the conditions that favored the production of these large burrows and account for their apparently unique development at Site 846, they appear to have persisted for more than 2 m.y.

\section{PALEOICHNOCOENOSIS AND "ICHNOFACIES" VARIATION IN EQUATORIAL PACIFIC SEDIMENTS}

Distinct deep-sea ichnofacies may be identified from the findings summarized above. An ichnofacies characterized by abundant Zoophy$\cos$, with common occurrence of stacked spreiten and very rare Chondrites, is characteristic of intervals having relatively high $(0.5 \%-1.5 \%)$ organic carbon contents (Pl. 3, Figs. 1-3; Pl. 5, Fig. 2). An ichnofacies having common, but isolated, Zoophycos spreiten is associated with the occurrence of more organic carbon- and diatom-rich interbeds; for example, at Site 847 (Pl. 3, Fig. 4). In the nannofossil oozes characteristic of Site 848 and the mid-Pliocene through Pleistocene age sections of Sites 849 through 851, Chondrites and Zoophycos are very rare, with the latter confined to occasional darker beds.

An ichnofacies distinguished by common Chondrites, but rare Zoophycos, is characteristic of the diatom nannofossil oozes and the foraminifer nannofossil oozes that dominate mid-Miocene to early Pliocene age sedimentation at Sites 846, 847, and 849 through 851 . Here, Chondrites is commonly associated with bluish-black, pyrite or monosulfide. Organic carbon contents within these sections are generally between $0.1 \%$ and $0.3 \%$.

Sections having sedimentation rates that are significantly less than $20 \mathrm{~m} / \mathrm{m}$.y. with alternating pale/dark brown beds contain a variety of trace fossils, including Planolites, Zoophycos, and less commonly, Chondrites, but are distinguished by the persistent presence of Skolithos, rare or absent in other ichnofacies. This Skolithos-bearing ichnofacies is characteristic of the off-equator sites (852 through 854), with typical $\mathrm{C}$ (org) concentrations of $0 \%$ to $0.1 \%$; (Mayer, Pisias, 


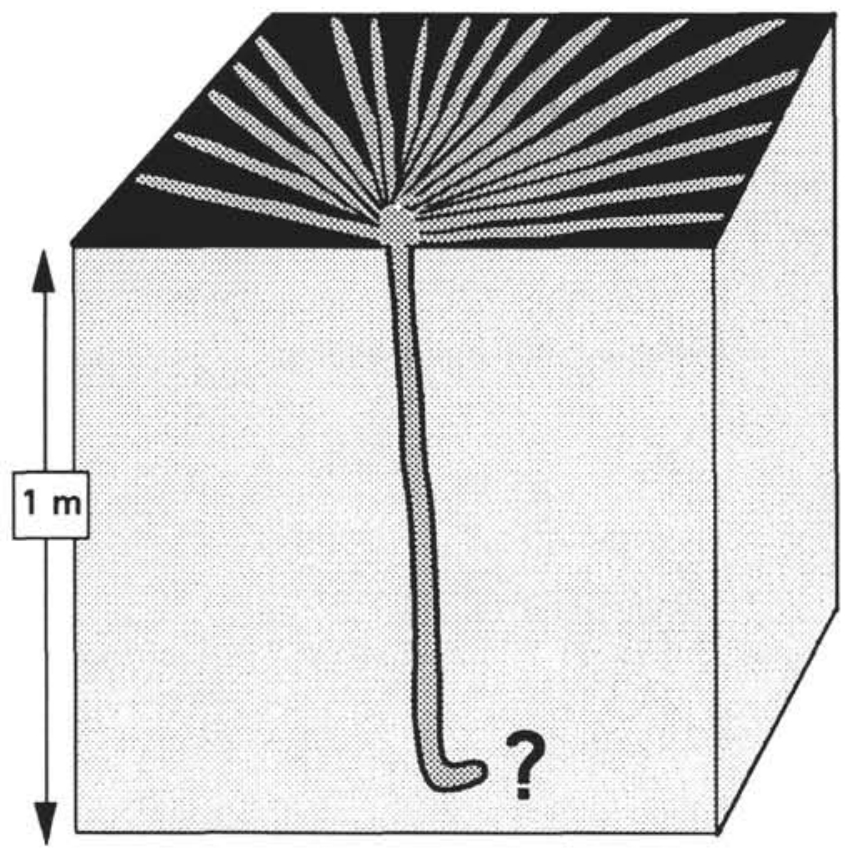

Figure 9. A deep-sea echiuran burrow: possible originator of the large subvertical burrows. Data from the cores cannot distinguish between the possibility of an $\mathrm{L}$ - or a $\mathrm{U}$-shaped burrow.

Janecek, et al., 1992) and some low sedimentation rate intervals within other sites, where less incentive existed for deeper burrowers.

\section{CONCLUSIONS}

The Neogene and Quaternary sediments of the eastern equatorial Pacific show considerable variation in the development of different trace fossils and trace-fossil assemblages that can be related to paleoenvironmental conditions.

An ichnofacies characterized by abundant Zoophycos with common stacks of spreiten is common in late Pliocene through Pleistocene age diatomaceous clay and diatom nannofossil ooze having relatively high $(0.5 \%-1.5 \%)$ organic carbon contents. Individual Zoophycos spreiten within diatom- and/or organic carbon-rich interbeds in nannofossil ooze further suggests an affinity for organic matter.

Chondrites is most abundant within Miocene through early Pliocene age nannofossil and diatom nannofossil oozes, especially in intervals exhibiting evidence of anoxic sulfidic early diagenesis. This association suggests an affinity of Chondrites with strongly reducing conditions that may also have suppressed other burrowers, such as Zoophycos.

The persistent presence of Skolithos only in off-equator sites characterized by oxidized sediments having low sedimentation rates (and in low sedimentation rate intervals in other sites) is consistent with the reduced activity of obliterating deeper tiers, such as Zoophy$\cos$ and Chondrites, which would be expected in sites having reduced organic matter.

At Site 846 located south of the Galapagos Islands, the normally deepest tiers, including Zoophycos, are cut by unusual subvertical, filled, and open burrows up to $1.1 \mathrm{~m}$ deep. These hitherto unrecognized structures are postulated to be the product of echiuran worms.

\section{ACKNOWLEDGMENTS}

I am most grateful to my fellow Leg 138 sedimentologists, who were persuaded to routinely record trace-fossil abundances during core description and to the expertise of Mark Gilmore and John Beck, who produced the photographic record shown in the plates. I thank Lawrence Hawkins for introducing me to echiurans. The manuscript was improved by the reviews of Mary Droser and Dave Bottjer.
Participation in Leg 138 was funded by the Natural Environment Research Council (United Kingdom).

\section{REFERENCES $*$}

Berger, W.H., Ekdale, A.A., and Bryant, P.P., 1979. Selective preservation of burrows in deep-sea carbonates. Mar. Geol., 32:205-230.

Berner, R.A., 1981. A new geochemical classification of sedimentary environments. J. Sediment. Petrol., 51:359-365.

Bromley, R.G., 1990. Trace Fossils: Biology and Taphonomy: London(Unwin Hyman).

De Vaugelas, J., 1989. Deep-sea lebensspuren: remarks on some echiuran traces in the Porcupine Seabight, northeast Atlantic. Deep Sea Res., 36:975-982.

Droser, M.L., and Bottjer, D.J., 1986. A semiquantitative field classification of ichnofabric. J. Sediment. Petrol., 56:558-559.

, 1991. Trace fossils and ichnofabric in Leg 119 cores. In Barron, J., Larsen, B., et al.,Proc. ODP, Sci. Results, 119: College Station, TX (Ocean Drilling Program), 635-641.

Ekdale, A.A., 1977. Abyssal trace fossils in worldwide Deep Sea Drilling Project cores. In Crimes, T.P., and Harper, J.C. (Eds.), Trace Fossils 2. Geol. J. Spec. Iss., 9:163-182.

1978. Trace fossils in Leg 42A cores. In Hsü, K.J., Montadert, L., et al., Init. Repts. DSDP, 42 (Pt. 1): Washington (U.S. Govt. Printing Office), 821-827.

1980. Trace fossils in Deep Sea Drilling Project Leg 58 cores. In Klein, G.deV., Kobayashi, K., et al., Init. Repts. DSDP, 58: Washington (U.S. Govt. Printing Office), 601-605.

Ekdale, A.A., and Berger, W.H., 1978. Deep-sea ichnofacies: modern organism traces on and in pelagic carbonates of the western equatorial Pacific. Palaeogeogr., Palaeoclimatol., Palaeoecol., 23:263-278.

Ekdale, A.A., Muller, L.N., and Novak, M.T., 1984. Quantitative ichnology of modern pelagic deposits in the abyssal Atlantic. Palaeogeogr., Palaeoclimatol., Palaeoecol., 45:189-223.

Fütterer, D.K., 1984. Bioturbation and trace fossils in deep sea sediments of the Walvis Ridge, Southeastern Atlantic, Leg 74. In Moore, T.C., Jr., Rabinowitz, P.D., et al., Init. Repts. DSDP, 74: Washington (U.S. Govt. Printing Office), 543-555.

Kemp, A.E.S., and Baldauf, J.G., 1993. Vast Neogene laminated diatom mat deposits from the eastern equatorial Pacific Ocean. Nature, 362:141-144.

Mayer, L., Pisias, N., Janecek, T., et al., 1992. Proc. ODP, Init. Repts., 138: College Station, TX (Ocean Drilling Program).

Ohta, S., 1984. Star-shaped feeding traces produced by echiuran worms on the deep-sea floor of the Bay of Bengal. Deep-Sea Res. Part A, 31:1415-1432.

Rachor, E., and Bartel, S., 1981. Occurrence and ecological significance of the spoon worm Echiurus echiurus in the German Bight. Veroeff. Inst. Meeresforsch. Bremerhaven, 19:71-88.

Swift, D.J., 1993. The macrobenthic infauna off Sellafield (North Eastern Irish Sea) with special reference to bioturbation. J. Mar. Biol. Assoc. U.K., $73: 143-162$.

Weaver, P.P.E., and Schultheiss, P.J., 1983. Vertical open burrows in deep-sea sediments $2 \mathrm{~m}$ in length. Nature, 301:329-331.

Wetzel, A., 1987. Ichnofabrics in Eocene to Maastrichtian sediments from Deep Sea Drilling Project Site 605, off the New Jersey coast. In van Hinte, J.E., Wise, S.W., Jr., et al., Init. Repts. DSDP, 93 (Pt. 2): Washington (U.S. Govt. Printing Office), 825-835.

1991. Ecologic interpretation of deep-sea trace fossil communities. Palaeogeogr., Palaeoclimatol., Palaeoecol., 85:47-69.

Wetzel, A., and Werner, F., 1981. Morphology and ecological significance of Zoophycos in deep-sea sediments off NW Africa. Palaeogeogr., Palaeoclimatol., Palaeoecol., 32:185-212.

Wetzel, A., and Wijayananda, N.P., 1990. Biogenic sedimentary structures in outer Bengal Fan deposits drilled during Leg 116. In Cochran, J.R., Stow, D.A.V., et al., Proc. ODP, Sci. Results, 116: College Station, TX (Ocean Drilling Program), 15-24.

- Abbreviations for names of organizations and publication titles in ODP reference lists follow the style given in Chemical Abstracts Service Source Index (published by American Chemical Society).

Date of initial receipt: 23 March 1993

Date of acceptance: 28 December 1993

Ms 138SR-110 


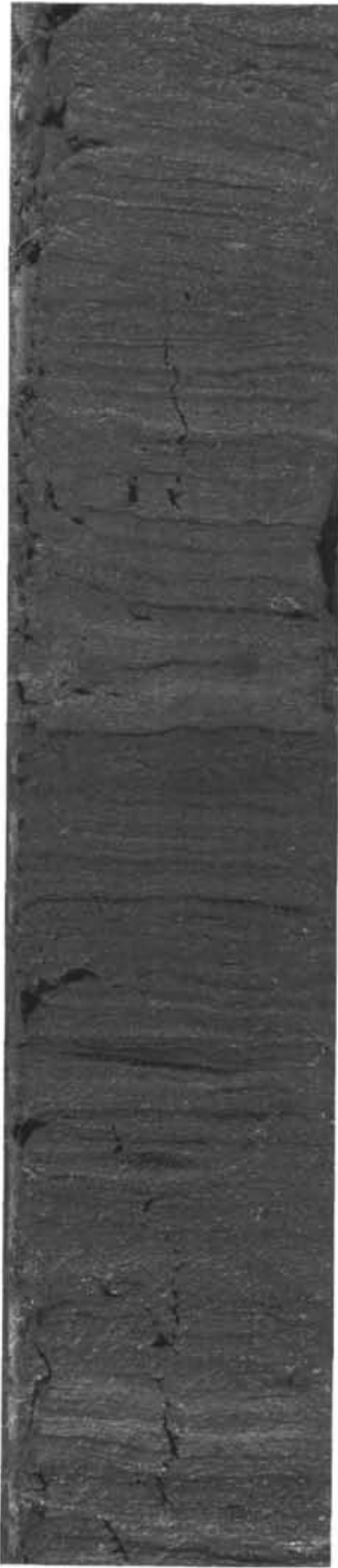

1

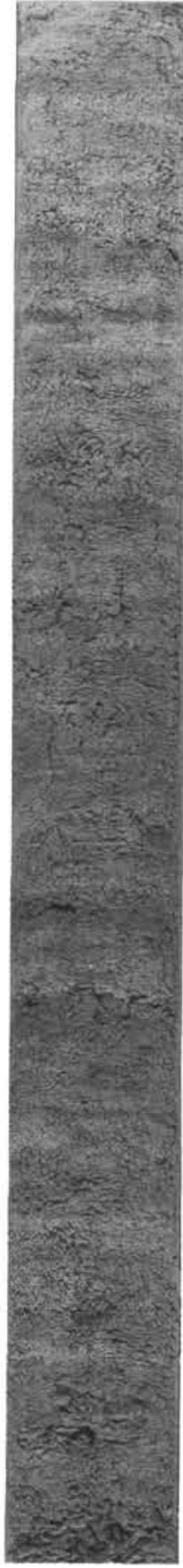

2

Plate 1. The effects of different core-cutting methods on observable structures. 1. Well-preserved laminations easily observable within laminated diatom ooze cut by the saw (Section 138-851B-29X-5, 60-85 cm). 2. Laminations are disrupted and obscured in wire-cut laminated diatom ooze (Section 138-849B-14X-3, 70-130 cm). Scale: full 6-cm core diameter is shown in both. 


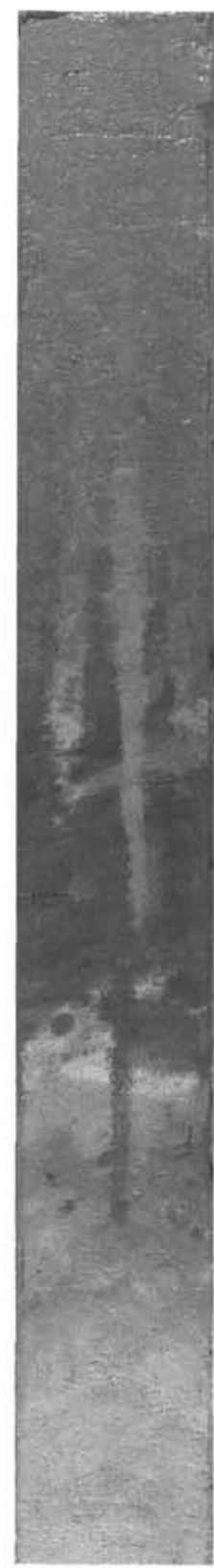

1
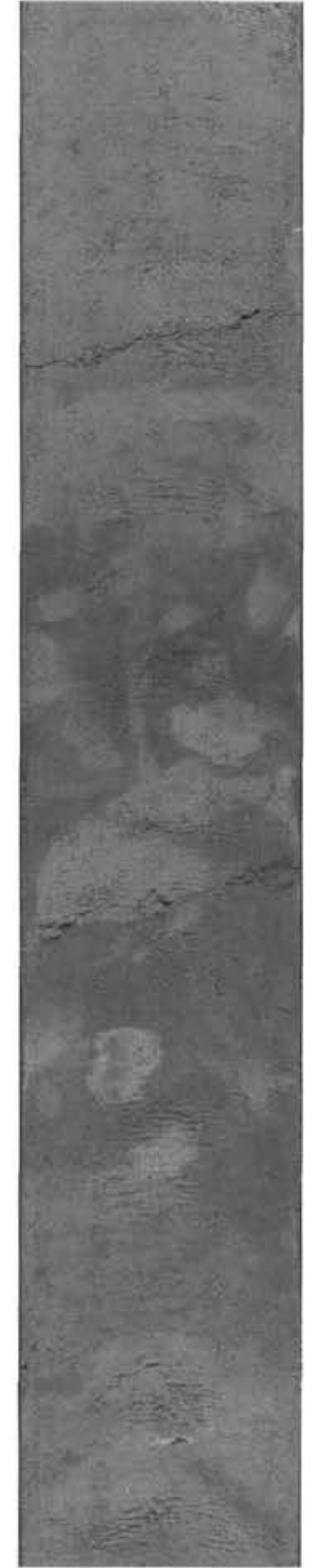

2
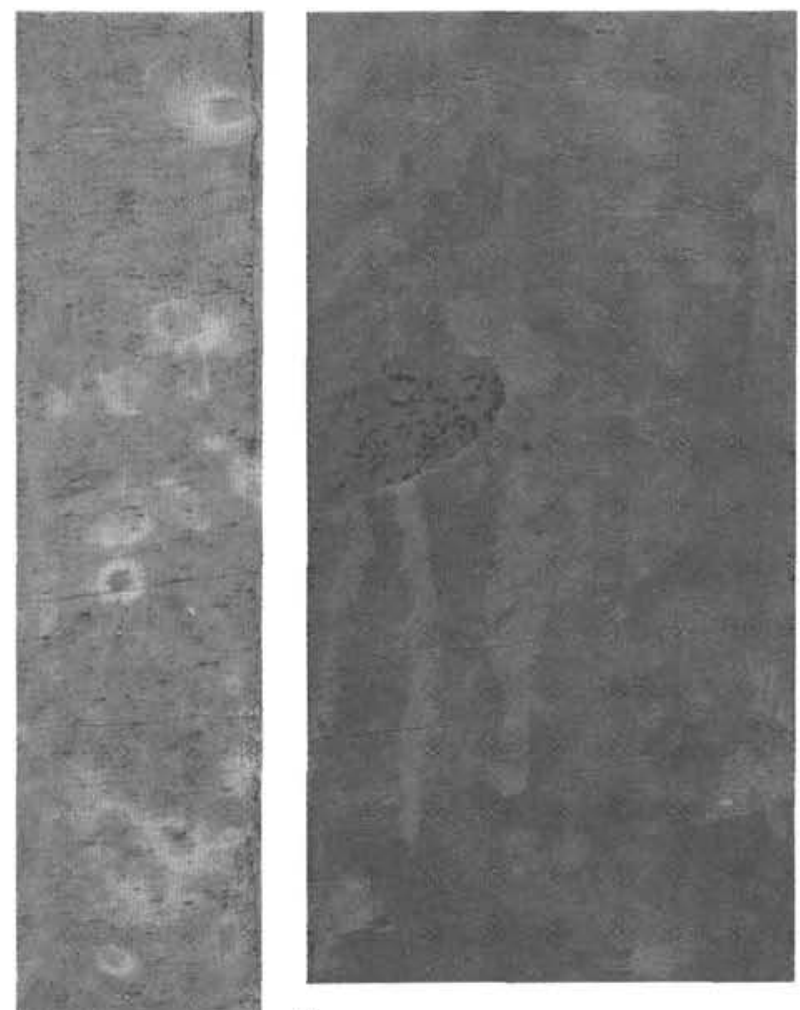

4

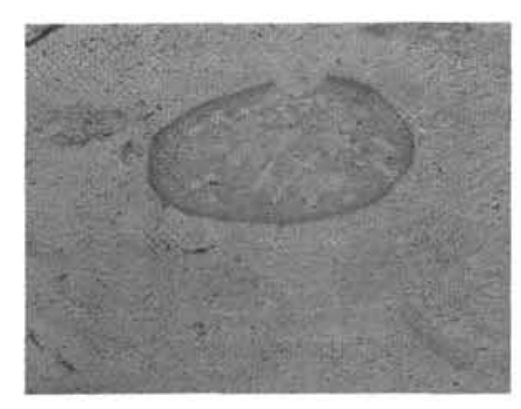

5

Plate. 2. 1. A core top with almost complete recovery of the sediment surface showing the surface mixed layer, the transition layer, and the historical layer with prominent Skolithos burrows (see Berger et al., 1979); Section 138-848A-1H-1, 0-60 cm). 2. Typical bedding and ichnofabric variation within Leg 138 cores, showing a high level of observable burrowing in the zone of sediment redistribution between the pale and dark beds, but almost no discernible burrowing within the paler lithology (Section 138-845B-16H-2, 85-128 cm). 3. Typical rind burrows with paler rinds (Section 138-848B-9H-5, 45-90 cm). 4. Chondrites within a Planolites burrow (Section 138-845B-15H-5, 40-62 cm). 5. Chondrites within a Planolites "halo" burrow (Section 138-844B-28X-6, 17-30 cm). Scale: full 6-cm core diameter is shown in 1-4; scale bar given in 5 . 


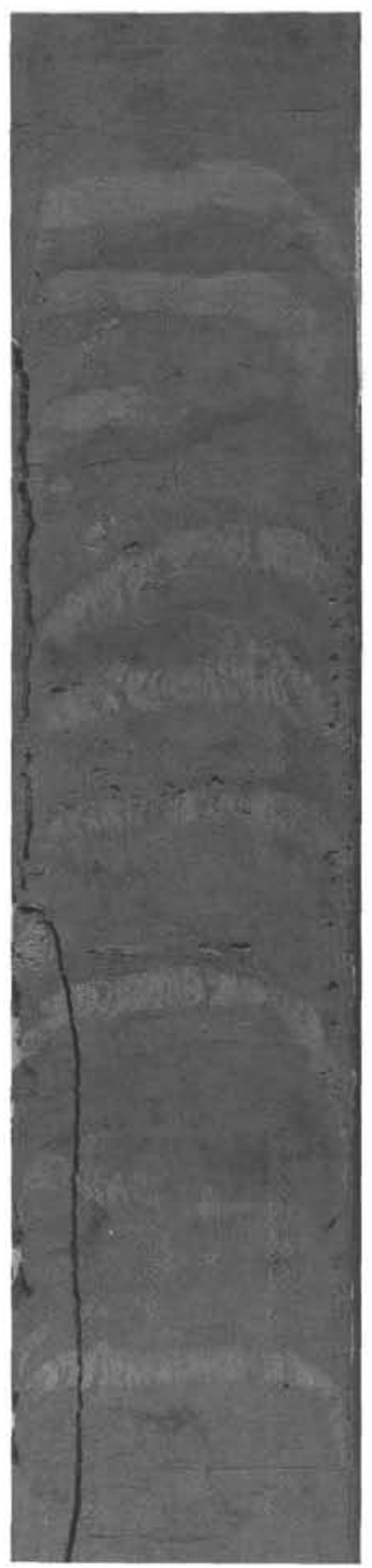

1

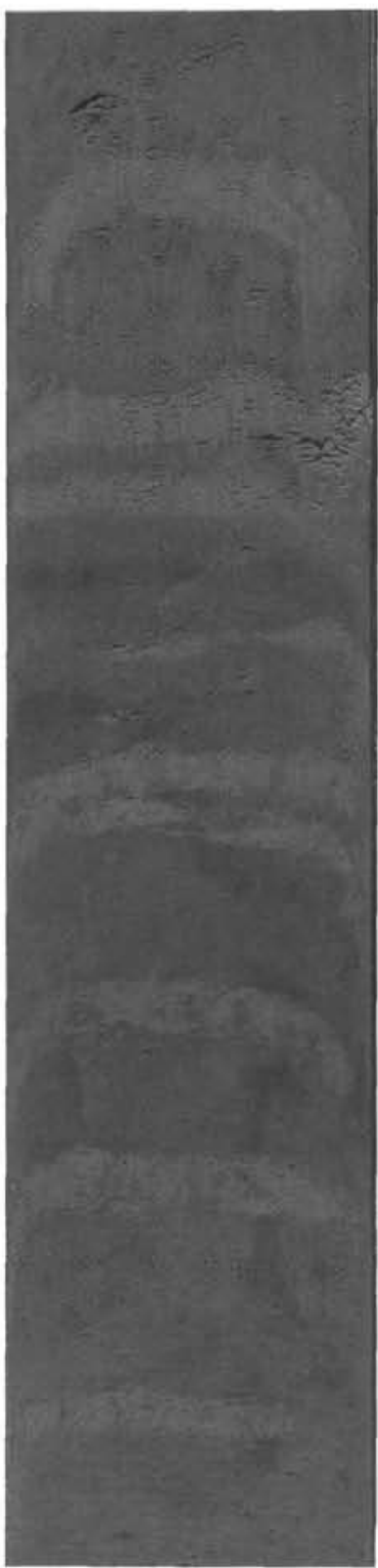

2
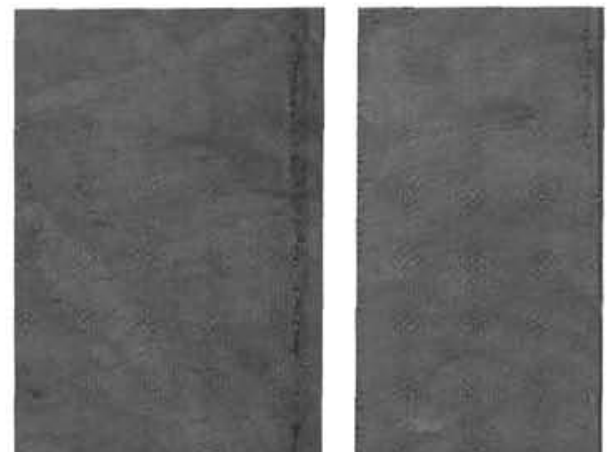

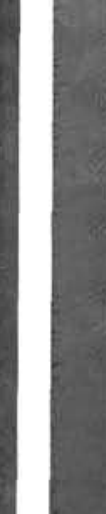


1
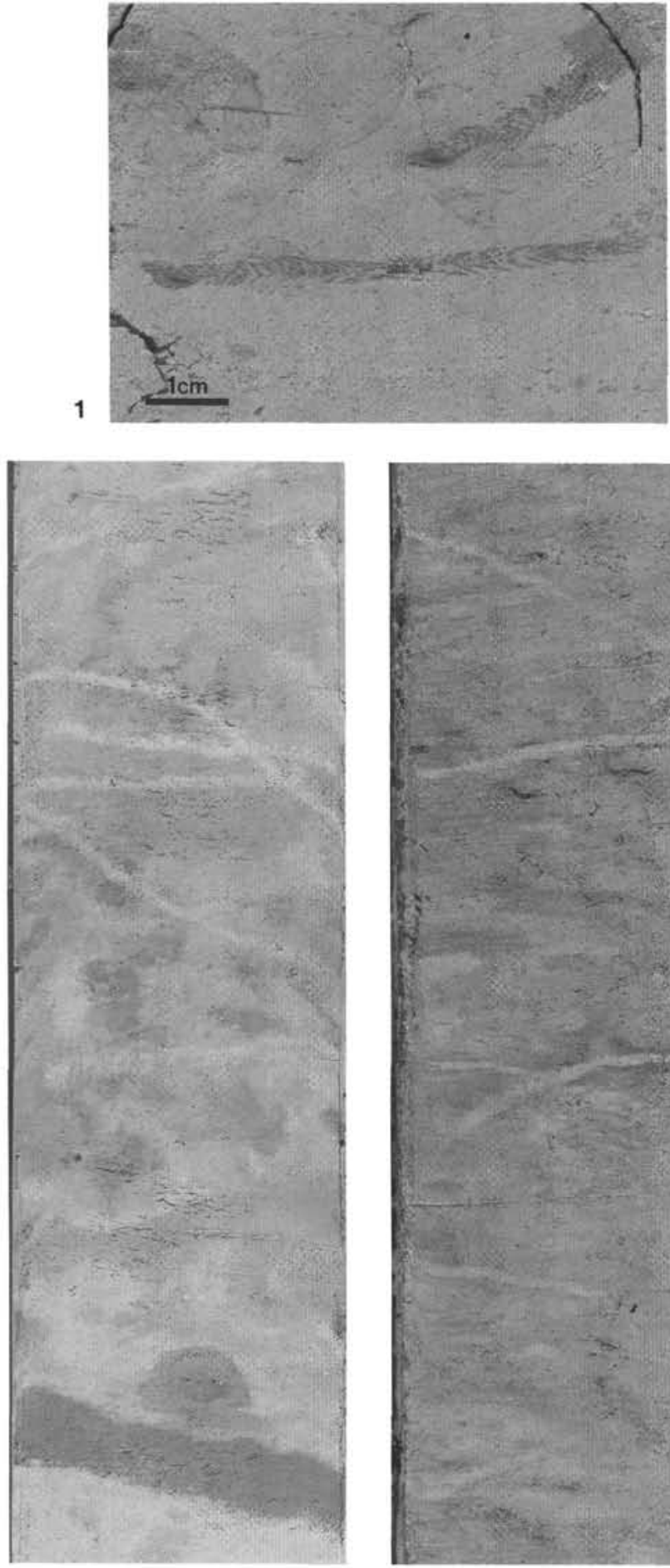

3

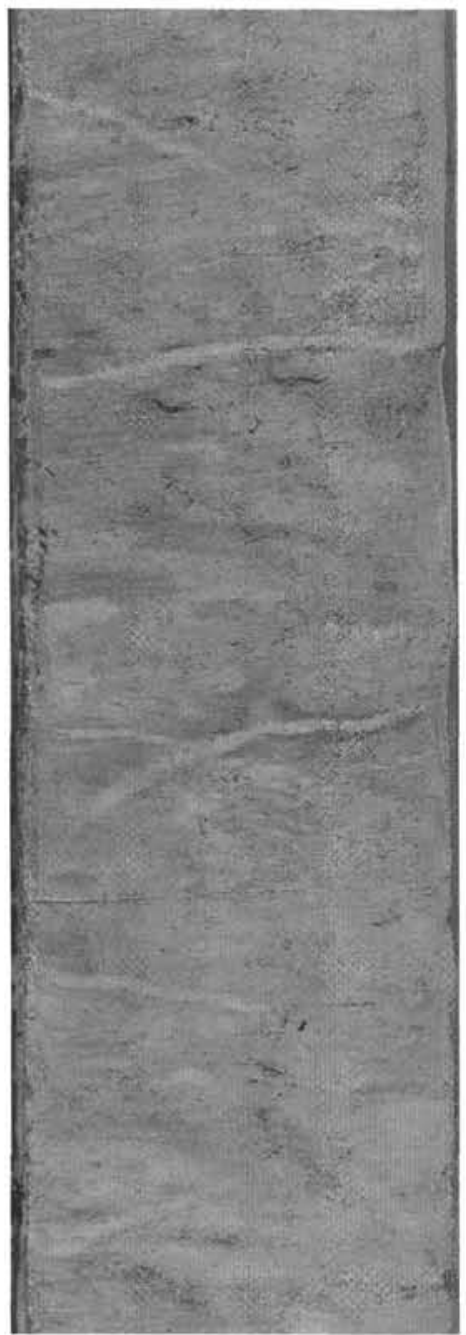

4
2
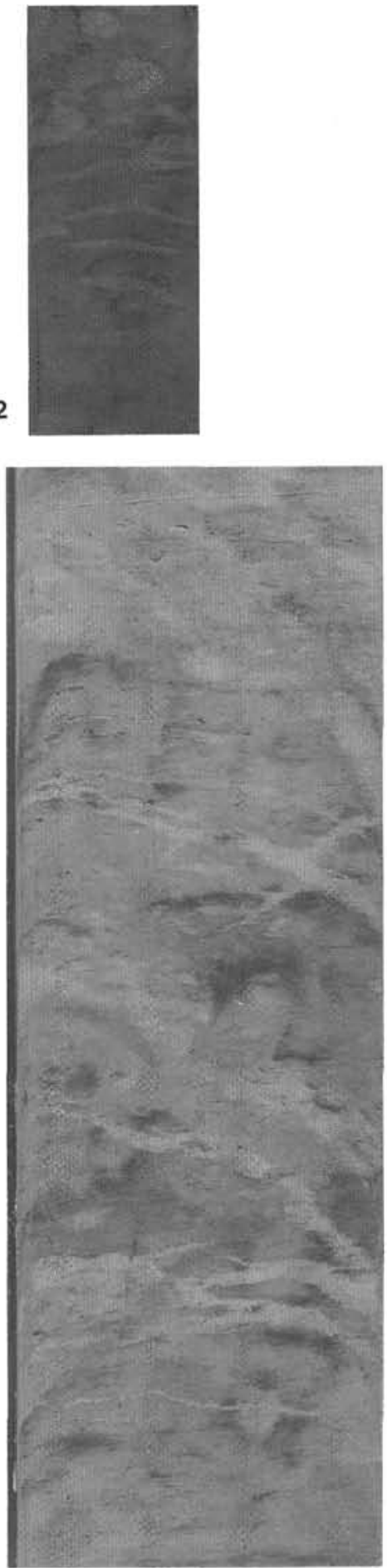

5

Plate 4. 1. Thin ( $2 \mathrm{~mm})$ Zoophycos burrows within radiolarian diatom nannofossil ooze/chalk at Section 138-850B-41X-2, 70-80 $\mathrm{cm}$. 2. Stack of Zoophycos spreiten in core Section 138-847B-6H-6, 65-120 cm. 3-6. Series of horizontal to inclined, cross-cutting, thin burrows (probable Zoophycos?) in (3) Section 138-844B-5H-3, 30-60 cm; (4) Section 138-846B-28X-4, 7-33 cm; and (5) Section 138-846B-2H-6, 26-50 cm. Scale: scale bar given in 1; full 6-cm core diameter is shown in 2-5. 


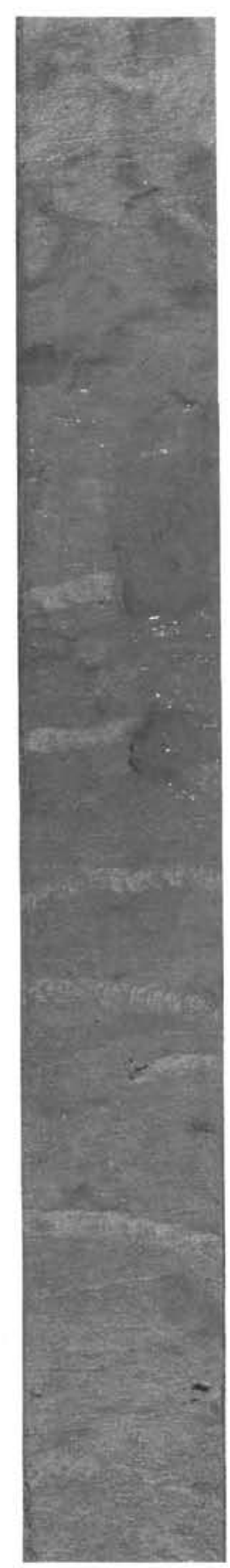

1

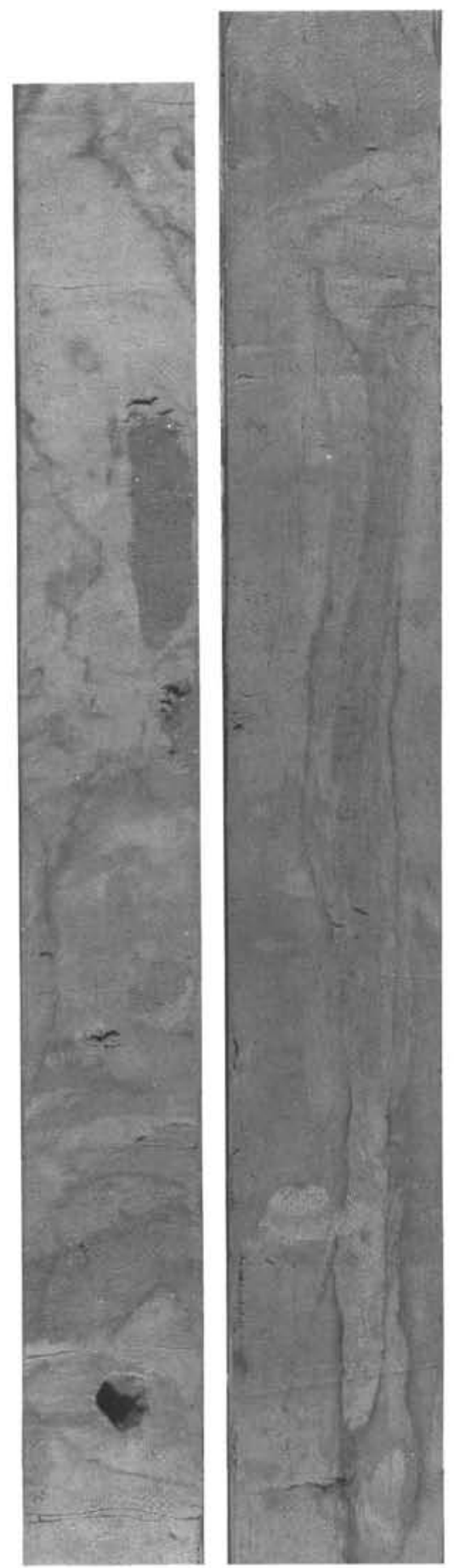

3
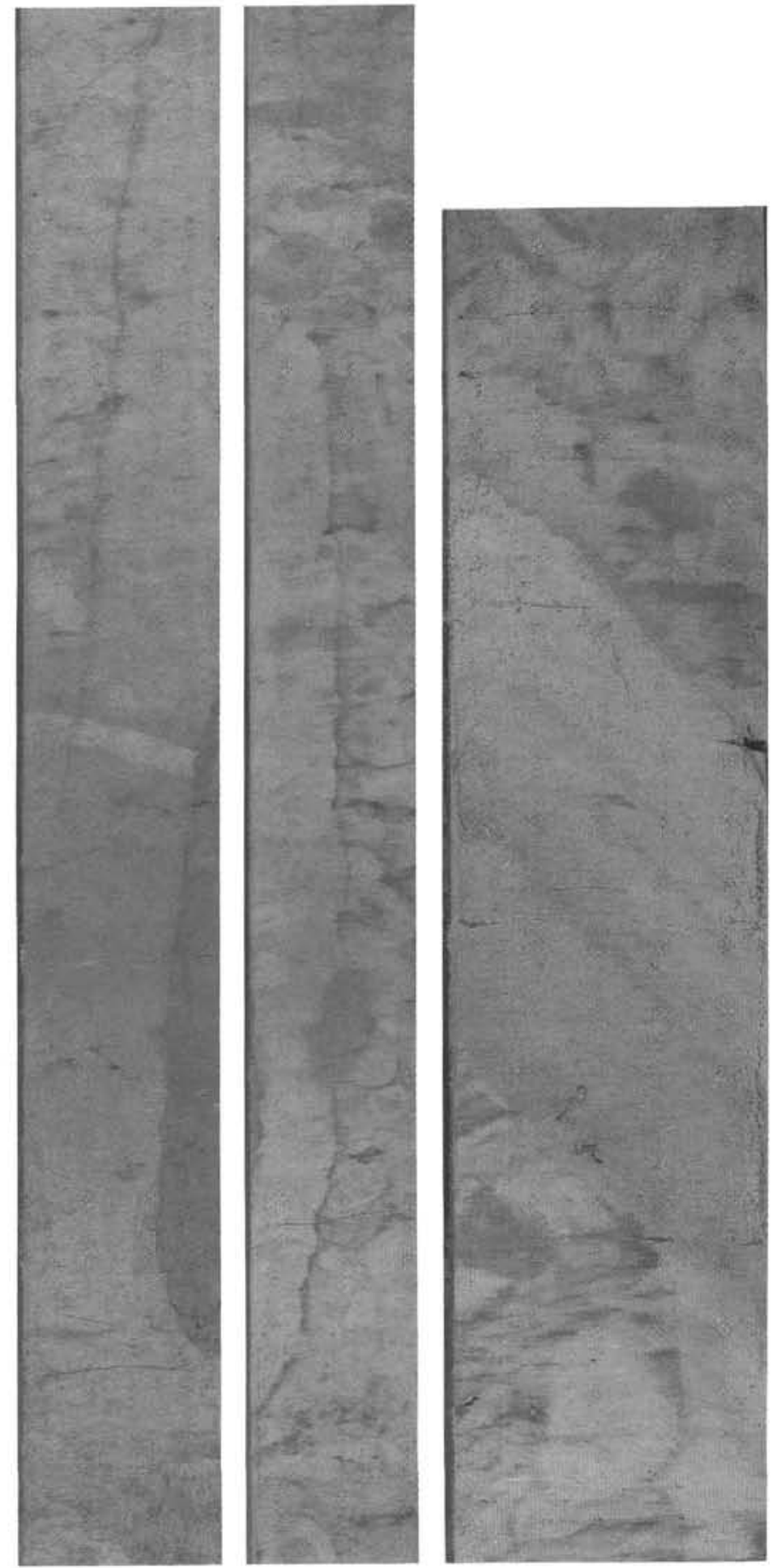

6

Plate 5. Large vertical burrows and open burrows-possible echiurid worm traces. In all cases, the diameter of the core is $7 \mathrm{~cm}$. 1. Two, approximately 2-cm-diameter, water-filled, open burrows cutting Zoophycos burrows (Section 138-846D-1H-2, 45-95 cm). 2. Top: darker (more foraminifer- and water-rich) sediment filling a subvertical 2 -cm-diameter burrow intersecting the core; note the associated diagenetic halo indicating an inclination of about $70^{\circ}$ above this. Bottom: irregular $1.5 \mathrm{~cm} \times 2 \mathrm{~cm}$ open burrow (with subhorizontal orientation) at $9.93 \mathrm{mbsf}$ in Section 138-846D-1H-4, 95-150 cm. 3. Long irregular trace of margin of subvertical burrow in Section 138-846D-3H-1, 48-95 cm. 4. Subvertical burrow intersecting core at high angle. The darker, subvertical (2-cm-thick) burrow clearly cuts a Zoophycos burrow. The burrow has an associated, vertically continuous, reaction-front about $4 \mathrm{~cm}$ from the burrow margin, allowing the burrow to be traced vertically beyond its direct intersection with the core. The burrow and halo curve round in an L-shape toward the bottom of the interval (Section 138-846D-4H-7, 25-75 cm). 5. The presence of a subvertical burrow is indicated by a reaction front that is not evident across outlines of traces of circular-ovoid burrows. The margin of the subvertical burrow intersects the core toward the base, and, downward, the burrow curves around away from vertical alignment (Section 138-846D-4H-5, 7-64 cm). 6. Large, tripartite, composite burrow structure cutting core obliquely (Section 138-846D-4H-5, 7-64 cm). Scale: full 6-cm core diameter is shown in 1-6. 